811.163.41'38

811.163.41 Вуковић Н. https://doi.org/10.18485/sj.2021.26.1.28

\section{МИЛОШ М. КОВАЧЕВИЋ}

Универзитет у Београду

Филолошки факултет

Универзитет у Крагујевцу

Филолошко-уметнички факултет
Оригинални научни рад

Примљен: 10. 11.2020.

Прихваћен: 12. 1. 2021.

\title{
СТИЛИСТИЧКИ ПРИНОСИ НОВА ВУКОВИЋА
}

У раду се даје преглед стилистичких доприноса Нова Вуковића представљених у књизи Путеви стилистичке идеје, која је без сумње најбољи стилистички приручник написан не само у србистици и/или сербокроатистици. У питању је стилистички приручник који се може мјерити с најбољим свјетским приручницима стилистике. У овом приручнику Ново Вуковић не заобилази ниједну чињеницу значајну за освјетљење историјата и актуелног стања стилистике: од разјашњења свих релевантних појмова и проблема стила и стилистике, до историјског пута стилистичке идеје, и то од њене антиципације у античкој реторици до врло комплексног актуелног стања.

Циљ нашег рада је да се расвијетле све битне стилистичке чињенице које доноси Вуковићева књига у контексту свјетских и посебно србистичких и/или сербокроатистичких стилистичких „учења”.

Кључне ријечи: Ново Вуковић, стилистика, лингвистичка стилистика, књижевна стилистика, развој стилистике, типови стилистике, стилистичке (под) дисциплине

"mkovacevic31@gmail.com 


\section{$*$ \\ $* *$}

Међу србистичким приносима стилистици врло значајно, ако не и најзначајније мјесто заузима уџбеник стилистике Путеви стилистичке идеје Нова Вуковића, књижевног теоретичара и критичара и професора Стилистике на Филозофском факултету у Никшићу. Као да је двијехиљадита, као година издања - на неки начин симболички осликала суштину ове Вуковићеве стилистичке књиге. С једне стране, она даје врло утемељену, критеријалну а критичку слику свјетских стилистичких „струјања” или „идеја” у ХХ вијеку, у коме је стилистика и стекла статус аутономне научне дисциплине, а с друге стране - она својом, оправдано је рећи, изузетношћу једноставно постаје „брана” објављивању површних, и научно некритеријалних не само стилистичких радова него и уџбеника, какве нам је у србистици „подаривао“ ХХ вијек. Стилистички уџбеник Нова Вуковића тако је међаш, посебно уџбенички међаш, у србистичким стилистичким погледима.

Србистика и иначе није богата уџбеничком стилистичком литературом, а и та литература по правилу је, до појаве књиге Нова Вуковића, парцијално стилистичка, јер се бавила само једним дијелом или аспектом стилистике: или а) оним лингвостилистичким (Ћорац 1974) 1 или поетскостилистичким (Анђелић 1930; Павловић 1960; 1969) или б) функционалностилистичким (Тошовић 1988), с тим да поетске или књижевностилистичке стилистике код Срба претходе оним лингвостилистичким. Књига Нова Вуковића доноси прегледно освјетљење свих стилистичких идеја, учења и теорија, како оних лингвостилистичких и књижевностилистичких, тако и оних функционалностилистичких. Уџебник стилистике Нова Вуковића још се по једној врло битној особини разликује од претходећих му србистичких уџбеника - Павловићевог (1969) и Ћорчевог (1974). Они су већ у времену свог настанка били анахронични, тако да нису имали никаквог утицаја на потоња стилистичка струјања у србистици. ${ }^{2}$ За разлику од њих, Вуковићев уџбеник у потпуности је у духу времена у коме је настао, ако не и испред њега ${ }^{3}$.

${ }^{1}$ Овдје не помињемо уџбеник Р. Симића (Симић 2000) јер је изашао из штампе исте године кад и Вуковићев уџбеник, али ни Симићев уџбеник из Опите стилистике (Симић 1998), јер се он тиче једног специфичног аспекта стилистичких „идеја“, које само дјелимично улазе у поље „стилистичких идеја“ Нова Вуковића. (О Симићевим доприносима стилистици в. Ковачевић 2018). Нисмо поменули ни стилистички уџбеник Милосава Чаркића (Чаркић 2002) будући да је настао послије Вуковићевог уџбеника, с којим се научно тешко може мјерити, без обзира о којем аспекту поређења је ријеч.

${ }^{2}$ О Ђ. Анђелићу в. И. Тартаља (2008), о М. Ћорцу - М. Ковачевић (2018а), о М. Павловићу - М. Ковачевић у књизи Српски стилистичари (у штампи).

${ }^{3}$ Да ће због своје „научности” ова књига имати мали приказивачки одјек у србистици скренута је пажња и на њеним промоцијама, на што подсјећају и ријечи С. Калезића: „За студију Путевима стилистичке идеје на промоцији у ЦАНУ речено је од стране изузетно квалификова- 
Ријетки су уџбеници не само код нас него и у свијету који се по различитим критеријумима могу поредити с овим уџбеником Нова Вуковића. По броју покренутих питања, по броју цитираних страних и домаћих стилистичара, по броју издвојених и освијетљених стилистичких термина, по методолошкој кохерентности и конзистентности текста, по начину научног презентовања стилистичких садржаја, по композиционој уобличености, а и по љепоти језика којом је писана - тешко да ова стилистичка књига Нова Вуковића има свој пандан не само у србистици.

Оно што прво пада у очи приликом њеног ишчитавања јесте начин структурисаности садржаја. Ново Вуковић је, наиме, књигу врло функционално, кохезивно и кохерентно структурисао. Сви садржаји су подијељени у два дијела. Први дио носи наслов О основним појмовима и проблемима стилистике, а други Пресјек развоја стилистичке мисли. Први дио је прегледно-проблемски, а други прегледно-историјски. Први је примарно теоријски, а други историјски. Први је куд и камо садржајнији и за схватање стилистике значајнији од другог. Други представља својеврсно историјско утемељење првог. Али и један и други повезује разматрање историјата стилистичког питања, представљеног кроз освјетљење стилистичке идеје.

Стилистичка идеја подразумијева „да стил постоји као феномен (теоријски, научни, семиолошки) који се може запазити, описати и проучавати”, с тим да се око ње, стилистичке идеје, „као неке врсте централне осе, постепено формира стилистичка мисао” (Вуковић 2000: 15)4. Тако је „идеја претпоставка стилистичке мисли”, и она ће „окупљајући и кондензујући стилистичку мисао, и довести, послије више од двадесет вјекова, до конципирања модерне стилистике" (15). Модерна стилистика је прије аутономна научна дисциплина неголи

них промотора да ће ова књига дуго бити осуђена на једну врсту ускраћености, на редуцирану рецепцију, јер ће код нас мало ко моћи да је мјеродавно, са одговарајућим разумијевањем чита" (Вуковић 2004:76).

Изаиста, књигу су приказ(ив)але само 3. Радуловић (в. Вуковић 2004: 42, 45, 50), а тај је приказ прештампан и у књизи: Радуловић (2004: 138-145), и Ј. Јовановић (2002: 159-165). На специфичан начин о овој је књизи говорила Ј. Јовановић Симић (2012: 241-248), у раду који је научно усмјерен „на метод Вуковићеве изградње текста као својеврсне стилске структуре, и на начин уградње релевантних мишљења с којима је при томе долазио у додир и сматрао их значајним делом сопствених погледа на предмет изучавања" (2012: 241). У раду ауторка најприје приказује како је Н. Вуковић у својој књизи представио различита схватања о стилу, а потом како се у „методологији изградње властитог текста и уградње ставова других аутор у њ он примарно служио трима поступцима: 1) поступком цитирања, тј. обликом „тзв. директног говора“, 2. „индиректним методом упућивања на туђа релевантна схватања”, тј. „препричавањем изворног текста”, и 3. поступком „ивичног текста”, тј. навођењем „напомена испод странице” (Јовановић Симић 2012: 244-246). А то су, заправо, општепримјењиви, истина различито реализовани, поступци у организацији сваког научног текста.

${ }^{4}$ При сваком наредном навођењу цитата из ове (Вуковић 2000) књиге наводићемо, из практичних разлога, само број странице са које је преузет дати цитат. 
наука. И своју аутономност везује за двадесети вијек, баш као и лингвистика у оквиру које је као науке најприје и утемељена. Као наука о стилу, стилистика у првом реду тражи одговор на питање: шта је то стил као њен предмет истраживања? А „стил као предмет стилистике један је од најнеухватљивијих и најконтроверзнијих међу појмовима којима оперишу хуманистичке науке" (17). Разлог је, прије свега, у томе што стилистика нема јасно успостављене границе „са тзв. 'сусједним' дисциплинама, тј. оним које се, с разних аспеката, баве језиком: лингвистике, поетике (теорије књижевности), реторике, семиотике", с тим да је, ипак, „најбитнији њен однос према лингвистиции и поетиции” (17).

Однос стилистике и лингвистике готово да је аксиоматичан, јер је „раширено мишљење да је стилистика лингвистичка дисциплина" (17), будући да је стил језичка појава, да се тиче употребе језика. За однос стилистике и лингвистике тешко се може рећи да је јасан и ослобођен недоумица. А недоумице изазива питање да ли је стилистика дисциплина лингвистике равноправна с неспорним лингвистичким дисциплинама какве су фонологија, морфологија, лексикологија и синтакса, или пак стилистика није дио лингвистике него је равноправна с њом. Будући да свака од лингвистичких (под)дисциплина има и свој стилистички аспект анализе (јер постоји фоностилистика, морфостилистика и сл.), онда се стилистика „појављује као нека врста паралелне алтернативе лингвистици” (18). Најчешће се „сматра да стилистика треба да се бави истим стварима којима и лингвистика, али са другог аспекта; с аспекта функционисања неке језичке структуре и њених експресивних могућности на том плану” (19-20).

Ништа мање није аксиоматичан ни однос стилистике и поетике, јер се стил одвајкада, чак и много прије инаугурисања стилистике као аутономне науке или научне дисциплине, сматрао поетичком категоријом. Стил је, тако, с једне стране нужно лингвистичка категорија, па је логично да је стилистика у најтјешњој вези са лингвистиком, а с друге стране, он је, будући да су стилске чињенице и естетске, односно умјетничке, нужно поетичка категорија па је стилистика логично у врло блиској вези са поетиком. Будући да су те естетске или умјетничке стилистичке чињенице изражавају језиком, „очигледно је да однос стилистика - поетика нужно увлачи у оптицај и однос поетика - лингвистика" (23). То најбоље потврђује лингвистичко-поетичка теорија знаменитог Романа Јакобсона, који „поетику интегрише у лингвистику”, јер се и једна и друга дисциплина баве „вербалном структуром”, с тим да је поетика нужно дио лингвистике као „глобалне науке о вербалној структури”. (23). Износећи ставове различитих аутора, прије свега лингвиста и књижевних теоретичара, и њихове покушаје да се одреди научни статус стилистике као посебне филолошке дисциплине или поддисциплине, Н. Вуковић преглед тих ставова закључује мишљу П. Гироа: „Стил је неодређен појам који стално превазилази границе у које намјеравају да га затворе” (26). 
Та реченица има кохезивно композициону улогу, јер нас директно уводи у поглавља које Н. Вуковић посвећује „проблемима одређења и дефинисања стила" (27). У одређењу и дефинисању појма стила Вуковић полази од тога да треба разликовати његово шире и уже значење. У ширем значењу „стил обухвата се људске дјелатности и садржаје и, уопштено говорећи, тиче се начина на који се нешто ради - од начина језичког изражавања па (чак) до начина понашања.” (28). „Начин” директно повезује стил у ширем и ужем значењу, будући да се „стил у ужем значењу везује за (природни) језик и књижевност као језичку умјетност”, представљајући „начин изражавања мисли посредством језика” (30). Притом стил у оба значења нужно у себи садржи „опште и индивидуално”, с обзиром на то да „човјек остварујући језичку комуникацију истовремено се и изражава, тј. у ту комуникацију, опет несвјесно или свјесно, уткива нешто од своје персоналности" (32). Из тога проистиче, а са чиме се слаже и већина стилистичара, да „стил није нешто ни сасвим индивидуално ни сасвим опште", јер су језик појединца и језик колектива нераскидиво повезани.

А на том односу индивидуалног и општег језика заснива се теорија стила као избора, као једна од најзначајнијих стилистичких теорија, а прва у низу теорија коју Н. Вуковић освјетљава. По тој теорији стил је избор који говорник врши између изражајних средстава које му пружа језик. Избор подразумијева да на сваком мјесту у језичком систему, и на нивоу свих језичких јединица постоји више синонимних и/или блискозначних јединица. Уз теорију стила као избора, Н. Вуковић освјетљава и: а) теорију стила као отклона од норме (стил по тој теорији представља разградњу и надградњу норме), б) теopију денотације и конотачије (при чему је денотативно опште значење неке јединице, а конотативно индивидуално, „асоцијацијама” надограђено опште значење, које се и поистовјећује са стилом), в) семиотичку теорију стила, која стил разматра у оквиру функционисања језичког знака, у ширем смислу тог појма, при чему „у конституисању стила важну улогу игра однос спољашњих и унутрашњих фактора знака" (46), и г) стил као својство текста, према којој стил представља „лингвистичко својство текста или већих текстовних организација, што примијењено на књижевно дјело значи да „дјело постиже свој сопствени израз, који није ни израз писца, ни израз епохе, него израз настао хармонизовањем, садејствовањем опште игре елемената у њему" (48).

Будући да је стил ,један од кључних елемената сваког дискурса” (50), а да су међу дискурсима за стилистику најзначајнији књижевни, поставља се питање на који начин вршити стилистичку анализу књижевног текста. Н. Вуковић том питању посвећује посебно поглавље, унутар кога врло јасно издваја темељне карактеристике неколико метода стилистичке књижевне анализе: а) метод Леа Шпицера, б) метод Мишела Рифатера, в) метод Емила Штајгера и Вофганга Кајзера, г) метод Виктора Виноградова, и д) метод Хенрика Маркијевича (50-59). Сучељавајући карактеристике датих метода, Н. 
Вуковић јасно показује шта су инваријанте, а шта специфичности наведених метода, истовремено указујући на њихове вриједности и недостатке.

Након што је освијетлио различите теорије стила и могућност њихове примјене у анализи конкретних књижевноумјетничких дјела, Н. Вуковић прелази на разматрање ,, подјела стилистике и њених различитих концепција ” (63). Притом, он наводи пет критеријума „према којима је стилистика као јединствена дисциплина конципирана или дијељена, с тим да они нису строго диференцирани, него „у именовању разних стилистика и њиховој подјели обично учествује више критеријума". А на основу тих пет основних класификационих критеријума - а то су: предмет, концепција или метод, намјена или циљ, перспектива и језички ниво - издвајају се сљедећи (терминолошки) типови стилистика.

Према критеријуму предмета стилистика се дијели на: стилистику колектива, стилистику појединца (генетичку стилистику), стилистику нациионалног језика (идиоматологију), стилистику књижевности, стилистику жанра, стилистику композииије, функционалну стилистика и т. сл.

Према критеријумима опите конщепције и метода издвојене су: лингвистичка стилистика (лингвостилистика), књижевна стилистика, психолошка стилистика, математичка (статистичка) стилистика, семиотичка стилистика, контрастивна стилистика, компаративна стилистика, стилистика кодирања и енкодирања итд.

Према критеријуму намјене (циља) настале су: нормативна стилистика, примијењена стилистика, интерпретативна стилистика, дескриптивна стилистика.

Према критеријуму перспективе издвајају се: синхронијска стилистика, дијахронијска (историјска) стилистика, семантичка стилистика, ономатологичка стилистика.

Према критеријуму језичких нивоа стилистика се дијели на: фоностилистику, морфоностилистику, морфостилистику, лексикостилистику, семантостилистику, графостилистику, стилистику текста (дискурса), макростилистику (60).

Од свих тих различито именованих стилистика Н. Вуковић издваја четири као најзначајније, као репрезенте модерне стилистике и њених савремених струјања.

Прва је лингвистичка стилистика (лингвостилистика) или дескриптивна стилистика директно произашла из женевске лингвистичке школе, а заснована је на језику колектива као систему, па се зато зове и колективна стилистика или стилистика израза, а инаугуратор јој је Сосиров ученик и колега Шарл Баји. 
Друга концепција модерне стилистике произашла је из минхенске књижевне школе, чији је утемељивач Карл Фослер, а сљедбеници Бенедето Кроче, Лео Шпицер и др. Она се не темељи на језику колектива, већ на језику појединца и, будући да се бави узроком употребе језичких средстава које је појединац одабрао из колективног језика, најчешће се назива генетичком стилистиком, али је позната и под именом књижевне стилистике, или пак стилистичке критике.

Уз те двије стилистике двадесети је вијек довео до развоја два нова, врло значајна типа стилистике: функиионалне стилистике и семиотичке стилистике. И управо ће тим типовима стилистике Н. Вуковић посветити преостатак првога дијела књиге, у коме ће детаљно и врло прегледно освијетлити различите погледе, на лингвистичку и генетичку стилистику у њиховим међуодносима, различитим варијантама и/или модификацијама.

Питања и развојни пут лингвостилистике Н. Вуковић даје врло прегледно и врло информативно, не изостављајући готово ниједну битну развојну нити теоријску чињеницу.

Творац лингвостилистике је Шарл Баји, који ју је, одређујући јој предмет истраживања, ставио насупрот лингвистици, јер лингвистика проучава појмовни, а стилистика афективни садржај језичких јединица, који представља јединство експресивне и импресивне компоненте језичког израза (Гиро 1994: 160). Као и сосировска лингвистика, стилистика се бави само колективним језиком и изразом, тако да из њеног предмета истраживања Баји искључује књижевност, будући да је она израз не језика колектива него језика појединца. Интересантно је да је „оснивач афективне стилистике Шарл Баји изопштио појам стил из своје стилистике (што је, свакако својеврстан парадокс) управо зато што тај појам, према његовом мишљењу, подразумијева димензију љепоте и као такав треба да припадне естетици" (22). Врло брзо ће, међутим, Бајијева „преуско замишљена афективност [само као природна и евокативна афективност] биће замијењена експресивношћу, што ће довести до укључивања књижевног израза у стилистику" (162), и то лингвистичку стилистику бајијевског типа. Од својих бајијевских почетака и током цијелог свог развоја лингвостилистика је покушавала да обухвати све видове језичког израза на свим нивоима лингвистичке анализе. Тако је њена подјела директно изведена из подјеле лингвистичких (под)дисциплина и њихових јединица. А минималну стилистичку јединицу, у складу са структуралистичком терминологијом, њен творац словачки стилистичар Јозеф Мистрик назвао је стилемом, која је минимална јединица појачане изражајности.

Подјела стилистичких дисциплина тако је паралелна подјели лингвистичких дисциплина, а подјела стилистичких јединица паралелна подјели лингвистичких јединица. Тако се лингвостилистика по правилу дијели на: 
1) фоностилистику, која изучава фоностилеме, као јединице стилског појачања на фонолошком и слоговном плану; 2) морфостилистику, која изучава морфостилеме, као јединице стилског појачања на морфолошком, односно творбено-морфолошком плану; 3) синтаксостилистику, која изучава синтаксостилеме као јединице појачане изражајности на синтаксичком плану, 4) семантостилистику, чија је основна јединица семантистолема као јединица појачајне изражајности ла лексиколошком плану.

У каснијем развоју лингвостилистике тим четирма стилистичким (под) дисциплинама додате су још двије: 5) графостилистика, која изучава графостилеме „као стилистичке интензификаторе на плану (орто)графије текста”, и 6) текстостилистика, која изучава текстостилеме, као јединице појачане изражајности на нивоу текста или дискурса (Прањић 1985: 193).

Ново Вуковић готово детаљно освјетљава шта све улази и на који начин стиче стилску изражајну вриједност у свим наведеним стилистичким (под) дисциплинама, искључујући текстостилистику, умјесто које даје посебно поглавље названо „Стилистика текста”. Тако се као фоностилистички садржаји наводе и освјетљавају: симболика гласова или гласовни (звучни) симболизам, па питања еуфоније, потом питања контекстуалне вриједности гласова, посебно с обзиром на фонетске фигуре настале гласовним понављањем (ономатопеја, асонанца, алитерација, алонжман, хомеотелеутон), као и „звучне акциденте” (какофонија, хијтус). Освјетљава се и значај синестезије као „обојеног слушања", али и питање интонације, и ритма и с њим нужно повезаних појава (метра, цезуре, акцента, риме и сл.).

За морфостилистичке појаве се констатује да „имају много мањи стилистички значај него фонолошке, посебно у нефлективним језицима" (78), па се најбитнијим морфостилстичким подручјем сматра подручје творбе ријечи, односно везивање стилске изражајности за суфикаслну и префиксалну творбу ријечи, односно за саоднос афикса унутар одређених творбених категорија, какве су нпр. деминутивност, аугментативност и сл. Указује се такође да се стилистичка изражајност на морфолошком плану може везати како за специфичну употребу појединих врста ријечи тако и за специфичне реализације појединих морфолошких категорија, као нпр. рода, броја, лица и падежа.

Семантостилистика по правилу изучава стилистичке функције ријечи, укључујући ту прије свега лексеме које репрезентују поједине лексичкосемантичке категорије (синониме, хомониме, парониме, антониме и сл.), као и поједине стилистичко-лексичке поступке (нпр. стилистичке варијанте, контаминаиије и сл.), потом тропе као семантичке фигуре (метафора, метонимија, персонификавција, алегорија, синегдиоха, хипербола и др.) и на крају нефигуративне а стилски маркиране слојеве лексике (варваризми, архаизми, историзми, неологизми и сл.). 
Синтаксостилистика изучава прије свега оне стилистичке појаве које се тичу синтаксичких категорија конструкција ријечи и реда ријечи. Ту прије свега спадају различити типови лирских паралелизама (анафора, епифора, симлока и др.), као и велики број различитих фигура што се могу подвести под „фигуре понављања” (асиндет, полисиндет, плеоназам, таутологија, кумулација, перифраза, елипса, силепса, реторичко питање и др.). Од осталих стилистички релевантних синтаксостилистичких поступака Н. Вуковић помиње поступке „тзв. дезорганизовања реченице”, као и поступке „отклона од уобичајеног реда ријечи" (дајући примјер инверзије), као и стилистички битна питања „обима реченице, распореда пауза у речници и ритма у реченици” (84).

У потпоглављу о графостилистици Н. Вуковић указује на то да „традиција писаног текста, посебно књижевног, зна за цио један арсенал поступака афективног наглашавања графичким путем. Ти поступци се у неким стилистичким номенклатурама називају фигуре писма” (86). Од тих „фигура писма” Вуковић помиње и коментарише употребу великог намјесто малог слова и обрнуто, потом графичке ономатопеје (нпр.: Траас!), па значај бјелина, посебно у поетским текстовима, затим улогу интерпункције, да би разматрање графостилистике закључио говором о конкретној и визуелној (фонетској) поезији.

Посебно, опширно поглавље Н. Вуковић у својој књизи посвећује најмлађој од (лингво)стилистичких дисциплина - стилистиц̧и текста (91-111). Будући да је традиционална и структурална лингвистика реченицу сматрала највишом лингвистичком јединицом, логично је да је лингвистика текста или дискурса најмлађа језичка дисциплина (заснована тек седамдесетих година XX вијека). Иако би се очекивало да је текст као виша јединица заправо „надреченично јединство”, ипак однос реченице и текста није тако јасно одредив, јер се у односу на текст или дискурс реченица дефинише као дио текста или дискурса који и сам може бити текст или дискурс. Због тога се Н. Вуковић, прије него што пређе на стилистику текста, бави врло критеријално - сучељавањем схватања различитих аутора, и то чак више књижевних теоретичара неголи лингвиста - о карактеристикама текста и/или дискурса, њиховом дефинисању и међуодносу. Потом прелази на проблем типологије текста или дискурса, издвајајући и освјетљавајући различите у литератури помињане типове текстова, као што су: писани и усмени текст; прича и дискурс; експлицуитни (аутономни) и имплицитни (ситуациони) дискурс; прича, описивање, аргументација, тумачење и дијалог; монолог и дијалог; приповиједање (нарација) и описивање (дескрипција); текстови ауторског и туђег говора; текстови сказа, и др. Сви ти типови текста првенствено се остварују у књижевности, тако да је књижевно дјело централни предмет истраживања, ако не лингвистике, онда свакако стилистике текста. У одговору на питање шта конституише готово сви истраживачи, истина у разним терминима, текстовне јединице и елементе текста, али се у њиховој идентификацији они увијек не подударају. 
У принципу, диференцирају се двије групе елемената: језички (формални) и тематски (садржајни). Док је језик обавезан конституенс књижевног дјела, остали, тзв. нејезички елементи (тема, прича, предметност, идеја итд.) нијесу. Управо, у тој двојности конститутивних елемената, стилистичари семиолошке оријентације виде и двије могућности стилистичког приступа тексту: један на плану језика (вербално-фонички, графички, синтаксички и семантички аспект), и други на плану изражавања (сложене релације унутар текста). Први приступ је, заправо, микростилистички, микроконтекстуални, синтагматски, други је макростилистички, макроконтекстуални, парадигматски. Први обично не обухвата веће сегменте и цјелине, док други то чини" (100-101).

Закључујући исцрпну, обавјештајну и врло критеријалну дискусију о лингвистици и стилистици текста, Н. Вуковић ће закључити да је ,јасно да модерна стилистика текста јесте књижевна стилистика” и да „сложеност и вишезначност књижевног текста и специфична (фигуративна) употреба језика у њему отварају овој стилистичкој грани широко поље истраживања" (110). Вуковићева прегледна анализа стилистике текста показала је да се „пут стилистике текста у великој мјери разилази са путевима стандардне стилистике”, али да „без обзира на то што се налази још у форми недовољно издиференцираног пројекта, та стилистика има будућност, можда баш зато што се у њеном хипотетичком пољу укрштају сви битни проблеми текста и књижевности као умјетности" (110-111).

Ако, по ријечима Н. Вуковића, „стилистика текста јесте књижевна стилистика”, наредно поглавље с насловом „Функционална стилистика”, показује да се стилистика, али она лингвистички усмјерена, бави свим типовима текстова, тј. да предмет стилистике није само књижевни текст него да су то сви типови текстова. Функционална стилистика, настала у окриљу Прашког лингвистичког кружока, бави се функционалним раслојавањем језика, у чијем резултату настају функиионални стилови као системске типичне употребе језика у одређеним типским ситуацијама (нпр. у публицистици, администрацији, науци, књижевности, свакодневној комуникацији и сл.). У прегледу развоја функционалне стилистике Н. Вуковић ће најприје указати и на антиципаторе ове стилистичке дисциплине (В. Хумболта, Бодуена де Куртенеа, Ш. Бајија, Л. Шћербу, Л. Јакубинског и др.), и посебно на Пражане, прије свега Б. Хавранека као творца функционалне стилистике, али и Р. Јакобсона и Ј. Мукаржовског. Н. Вуковић показује да је „дефинисање стила као функционалностилистичке категорије имало релативно дуг пут, од Хавранекових радова па до 80-их година XX вијека" (114), наглашавајући да је тразвоју функциопналне стилистике највише допринијела совјетска школа функционалне стилистике, чији су главни представници В. Виноградов, М. Н. Кожина и В. П. Мурат.

Након освјетљења појма функционаног стила и кратког приказа развојног пута функционалне стилистике, Н. Вуковић ће, ослањајући се на књигу 
Б. Тошовића о функционалним стиловима (Тошовић 1988), констатовати да је између различитих типологија функционалних стилова најближа општеприхваћеној она која издваја пет типова функционалних стилова: књижевноумјетнички, публицистички, научни, админстративни и разговорни. Притом границе између појединих стилова нису оштре, тако да постоје и међустилови, а сваки од стилова има своје подстилове, а подстилови по правилу и своје жанрове. Н. Вуковић ће укратко представити основне карактеристике сваког од наведених функционалних стилова, и то како понаособно тако и релационо, посебно према књижевноумјетничком стилу (па се посебно разматра суоднос разговорног и књижевноумјетничког стила, и научног и књижевноумјетничког стила).

Давши врло обавјештајан преглед типова лингвостилистике и као лингвистичке и као књижевне стилистике, и приказ стања у стилистистици текста и функционалној стилистици, Н. Вуковић након тога у посебном поглављу, посљедњем у првом дијелу књиге, расправља о „проблемима стилистике”. Којим „проблемима”, ако се и сва претходна поглавља баве стилистичким проблемима? У ово поглавље укључени су, међутим, проблеми који или нису обухваћени претходним поглављима, или су у њиима тек мимогредно помињани. Зато би овом поглављу више одговарао наслов „посебни проблеми стилистике", који се по правилу не односе на темељне, него прије на пратилачке стилистичке идеје, које шире методолошко или емпиријско поље стилистичких истраживања. Н. Вуковић издваја осам посебних „стилиситичких проблема”, сваки прегледно а концизно образлажући. А то су: 1) проблем идиоматологије, која подразумијева проучавање „националних стилова”, односно „проучавање националних језика као посебних стилова" (120); 2) проблем стилистичке композиције, која је претходница стилистике текста; 3) проблем односа стила и писаға, који је посебно истицао Р. Барт, сматрајући да је, уз језик и стил, писање „трећа димензија форме”, будући да су ,језик и стил објекти”, а „писање је функција: оно је однос између стварања и друштва, оно је књижевни језик преображен друштвеном намјеном”, тако да се „писање ситуира између језика и стила као феномен пишчевог избора, који носи пишчеву идеологију, а осим тога и својства жанра, владајућу поетику, моду и сл." (124); 4) проблем односа стилистике и књижевне критике, будући да је „цијела једна оријентација у књижевној критици, чији су јој протагонисти и дали назив стилска критика, ишла у смјеру преферирања стилских вриједности књижевног дјела" (126), 5) проблем односа језика и мисли, који је „важан стилистички проблем, а који подразумијева три различита приступа: „рационалистички - према коме мисао претходи језику, романтички - према коме мисао и језик иду паралелно и језички - према коме језик претходи мисли и управља њом" (127-128); 6) проблем односа синхроније и дијахроније, који је проистекао из Сосиров(ск)ог става о строгој раздвојености та два плана анализе, и примату синхронијског 
над дијахронијским аспектом, тако да је тај Сосиров став „утицао пресудно да се стилистика профилише као синхронијска дисцилина" (129), чему насупрот стоји чињеница да „књижевност не сачињавају само савремена дјела, односно дјела писана савременим језиком, већ и она настала у ранијим вјековима" (130); 7) проблем упоредне стилистике, на који је указао П. Гиро, сматрајући да је стилистика „компаративна по дефиницији”, јер „почива на упоређивањима разних врста: језика писаца, језика различитих дјела или различитих епоха, различитих националних језика (идиоматологиоја) и т. сл., тако да је могуће замислити стварање и упоредне стилистике. (131), и 8) проблем односа стилистике и статистике, који постаје посебно актуелан откад су „у подручје стилистике ушле теорија вјероватноће, теорија информације, теорија комуникације, семиологија, топологија, кибертнетика”, тако да се „феномени стилског и поетског почињу третирати као информација" (132), самим тим намећући и питање стварања статистичке стилиситике као посебне стилистичке (под)дисциплине. Свим овим проблемима треба додати још један, данас врло актуелан, о коме Н. Вуковић не говори, а то је проблем односа стилистике и интернета, тако да неки стлистичари не само да говоре него и монографије пишу о „интернет-стилистици” (в. Тошовић 2015).

*

У другом дијелу свог уџбеника Н. Вуковић даје преглед развоја стилистичке мисли (139-216). Почетке стилистичке идеје Н. Вуковић везује за античку Грчку и Рим, и то у оквиру реторике као науке о бесједништву. Изумитељем реторике сматра се грчки филозоф Емпедокле, који је живио у V вијеку п.н.е. на Сицилији. Најзначајнију античку грчку реторику написао је Аристотел, који и јесте први реторичар чије погледе у својој књизи представља Н. Вуковић. Аристотелова Реторика састојала се од три књиге, с тим да су прве двије посвећене теорији аргументације, а трећа теорији лексиса (латински термин: elocutio) и теорији композиције. Теорија лексиса прави разлику између бесједничког (прозног) стила, који подразумијева умјетност комуникације односно обраћања обичној публици, и пјесничког стила, који представља умјетност сликовитог изражавања, али не улази у предмет Peторике, него у предмет Аристотелове Поетике. За добре особине бесједничког стила Аристотел сматра јасноћу, прикладност и отменост" (141). Као утемељивача стилистичке идеје Н. Вуковић наводи Аристотеловог ученика Теофраста, који се највише бавио лексисом, посебно у својој књизи $O$ стилу. Теофраст истиче четири основне особине доброг стила: јасност, тачност, прикладност и украшеност. Он област стила дијели на три подручја: избор ријечи, композиција (хармонија) и фигуре, и издваја три врсте стила: ниски (genos ishón), средњи (genos méson) и узвишени (genos megaloprepés). 
Грчка реторика, посебно Аристотелово реторичко учење, добила је своју разраду и Риму. Од римских реторичара Н. Вуковић укратко представља Цицеронова реторичка схватања, а посебно се задржава на Квинтилијановом реторичком дјелу Insttutionis oratoria („О образовању говорника”) као „најпотпунијој синтези античких реторичких идеја” (146). Од пет дијелова реторике: inventio, dispositio, elocutio, actio или pronuntiatio i memoria Н. Вуковић се детаљно задржава на карактеристикама елокуције (elocutio) која се бави стилским и језичким дијелом бесједе. У том дијелу Квинтилијан се бави трима тематским подручјима: подручјем ријечи, подручјем реченице и подручјем украса. За прво подручје као битне издваја природност (усаглашеност ријечи и страви), употребу ријечи из свакодневног говора и избор ријечи са највећом изражајном снагом. За друго подручје битни су јасноћа и правилност. Квинтилијан највише пажње поклања трећем подручју, тј. украсима, дијелећи то подручје на тропе и фигуре, а фигуре даље на фигуре ријечи и фигуре мисли, притом сматрајући да сви фигуративни изрази настају на основу четири типа трансформација: adiectio (додавање), detractio (одузимање), imutatio (замјена) и transmutatio (премјештање). У свом даљем развоју, почев од ренесансе и Луиса Вива, па све до нестанка из школског система у првој половини XIX вијека, петодјелна се реторика сводила на стилистику, постајала је сужена реторика, задржавајући од пет својих дијелова само elocutio. Сужена реторика довела је до гашења традиционалне реторике и њеног прерастања у поетику, а цијели elocutio свео се, посебно у XVII, XVIII и XIX вијеку, на теорију и класификацију стилских фигура.

Након врло обавјештајног прегледа стилистичких идеја у оквиру реторике, од њених почетака па све до средине XIX вијека када је „искључена” из школског система, Н. Вуковић ће у сажетку и дати сљедећих пет (образложених) закључака о суштини стилистичке идеје у традиционалној реторици.

(1) Стил је у традиционалној реторици посматран као једна врста украса, што ће рећи додатка.

(2) Стара реторика је суштину стилистичких проблема смјештала у трећи дио реторичког поља - у elocutio.

(3) Реторичка стилистика, да употријебимо тај условни термин, била је априористичка и нормативна: настојала је да попише и озакони критеријуме настанка текста.

(4) Чврста веза између стила и рода у великој мјери је профилисала стару реторику, односно њен стилистички дио.

(5) Реторичка стилистика је већ од самих почетака представљала релативно уско подручје. Свела је своју пажњу, углавном на: учење о фигурама, учење о родовима и врстама стилова који им одговарају и учење о ријечима и конструкцијама које кваре добар стил (153-155). 
Стилистичких идеја и теорија и није било између „реторичке” и „модерне" стилистике. Модерна стилистика продукт је XX вијека, с тим да су, како Н. Вуковић каже, „систематичнија истраживања стила у XX вијеку кренула у три основна правца. Један је произашао из лингвистике, други из психологије, а трећи из науке о умјетности”. Будући да Н. Вуковића прије свега занима лингвистичка и књижевна стилистика, он ће њихово заснивање и приказ освијетлити у оквиру три поглавља, која одражавају три лингвистичко-књижевна стилистичка правца: 1) лингвистички праваи, 2) интерференција лингвистичког и књижевног правияа и 3) генетички правац.

Лингвистички правац у стилистици започиње женевском школом, с тим да Ф. де Сосир као утемељитељ женевске школе није утемељитељ и лингвистичке стилистике. Оснивач стилистике у оквиру женевске школе, која се сматра и првом модерном, научном стилистиком, јесте Шарл Баји, Сосиров ученик, колега и насљедник на Катедри у Женеви. Баји је први који је јасно одредио предмет стилистике, уз критеријуме разграничења лингвистичких и стилистичких чињеница: „Стилистика проучава чињенице језичког израза с гледишта њиховог афективног садржаја, тј. израз осјећајних чињеница језиком и дјеловање језичких чињеница на осјећајност" (Гиро 1964: 38).

Да би одредио шта је то „афективно”, Баји разлаже језички израз на његове три компоненте: 1. појмовна или комуникативна компонента израза (коју изучава лингвистика), 2. експресивна компонента, мање-више несвјесна вриједност израза, која „одсликава” говорника; 3. импресивна или интенционална вриједност израза (изразом се настоји произвести утисак на саговорника). Сваки израз на било ком нивоу језика има ту троструку вриједност. Експресивна и импресивна компонента исказа представљају стилистичке вриједности, а појмовна чисто комуникативну вриједност исказа. Експресивна и импресивна вриједност исказа чине афективни садржај језика, а тај је садржај предмет стилистике. Афективна обиљежја као предмет стилистике, по мишљењу Бајија, могу бити двострука: 1) природна (која се темеље на мотивисаности језичког знака) и 2) накнадно стечена евокачијом (што подразумијева преношење израза из примарног у њему неприродни секундарни контекст). Бајијева стилистика везује се, баш као и Сосирова структурална лингвистика, само за језик колектива. Зато је Баји искључио књижевност из сфере стилистичких истраживања. По Бајијевом мишљењу, „афективни аспекти се у свој својој чистоћи налазе само у обичном језику, док се литерарне форме удаљавају од тог стања на два начина: увијек су мање-више индивидуална креација и имају естетску интенцију" (161).

Велики је број бајијевски утемељених стилистичара, само што су они, мијењајући термин афективност термином експресивност, проширили поље истраживања бајијевске лингвистике, укључујући у њ и књижевна дјела. 
Вуковић ће тако у оквиру лингвистичког правца стилситике представити још двије стилистичке школе: школу руских формалиста, и прашку школу (школу прашкога круга). Руски формалисти су врло значајни за развој лингвистилистике, прије свега по томе што су у центар истраживања ставили форму а не садржај језичких јединица, тако да су остварили значајне резултате на плану поетске фонетике, посебно анализом тзв. заумног језика (језика у коме је потпуно укинут смисао). Најзначајнији допринос формалиста свакако се односи на дефинисање пјесничког језика, којему је супротстављан непјеснички језик. Књижевно дјело, које је било у центру њиховог истраживања, било је за њих „само случај поетског језика, али не и услов тог језика” (165). Код формалиста је термин стил имао двоструко значење: а) „поступак обликовања и трансформације грађе”, и б) „избор језичких средстава” (165-166). Истраживања руских формалиста обухатала су „многе стилистичке теме: питање односа обични (комуникативни) језик (стил) - пјеснички језик (стил), питање односа звуковни слој - значењски слој у вербалној структури, проблем веза између метричког система и синтаксе и семантике текста, проблем значаја и избора граматичких категорија за реализацију књижевног исказа, нека питања теорије стилизације итд." (166).

Прашки круг „представља једну од најплоднијих лингвистичко-књижевних школа у XX вијеку”. Уз велике лингвистичке доприносе, Пражани су дали и врло значајне стилистичке доприносе. Посебно Б. Хавранек, Ј. Мукаржовски, Р. Јакобсон и С. Карцевски.

Пражани су творци функционалне стилистике, као теорије о функционалним стиловима. Заправо, истински утемељитељ функционалне стилистике у оквиру Прашке лингвистичке школе јесте Бохуслав Хавранек. У својим радовима посвећеним теорији књижевног језика Хавранек је трасирао пут развоја функционалне стилистике. У тим радовима Хавранек констатује да књижевни језик није јединствен него се диференцира зависно од својих социјалних функција. А та диференцијација је условљена екстралингвистичким факторима. Књижевни језик се битно разликује од осталих идиома, посебно од народног језика, јер је народни језик једнодимензионалан (готово се своди само на комуникативну функцију), док је књижевни језик функционално поливалентан. Хавранек, што је најбитније за функционалну стилистику, за диференцијацију типова употребе књижевног језика издваја критеријуме интелектуализачије, аутоматизачије и актуализачије језичких средстава. Интелектуализација представља апстрактан начин изношења свеколике сложености мисли па је стога најизразитије присутна у научном стилу књижевног језика. Термин аутоматизација Хавранек је преузео из психологије да би означио употребу језичких средстава која сама по себи не привлаче пажњу. Супротно њој, актуелизацијом језички израз привлачи на себе пажњу и доживљава се као нешто необично, лишено аутоматизма, дезаутоматизова- 
но. Хавранек управо аутоматизацију и актуелизацију узима као критеријум диференцијације стилова: актуелизација има поетски језик, а аутоматизација научни, административни и разговорни стил. Значајан допринос стилистици дао је и Роман Јакобсон, посебно издвајањем као посебне поетске функиије језика, која је битно различита од свих осталих, будући да је усмјерена на сам израз. Уз издвајање поетске функције, Јакобсон је познат и по издвајању доминанте као најбитнијег елемента унутар скупа елемената који чине једно књижевно дјело. Доминанта, која је за Јакобсона кључ за анализу књижевног дјела, јесте „средишња компонента умјетничког дела: она усмерава, одређује и преображава остале компоненте”, јамчећи при том „за целовитост структуре" (168).

Након анализе лингвистичког правца стилистике, датог кроз приказ трију лингвистичко-књижевних школа - женевске школе, школе руских формалиста и прашке школе - Н. Вуковић даје преглед стилистичких учења у којима долази до интерферениије лингвистичког и књижевног правиа. Најприје представља стилистичке погледе представника феноменолошког поимања стила, а то су: Волфганг Кајзер из Њемачке као заступник метода иманентне интерпретаuије, и Емил Штајгер из Швајцарске као оснивач „циришке школе”, који је такође примарно заступник метода иманентне интерпретације.

Кајзерова књига Језичко умјетничко дјело (1948) дала је, по Н. Вуковићу, најбољу концепцију стила дјела. „Кајзер је”, по ријечима Н. Вуковића, „направио најпотпунију синтезу феноменолошке мисли о књижевнопсти, спајајући у свом дјелу сва важна достигнућа овог антипозитивистичког правца", тако да је она „сигурно најобухватније и најдосљедније теоријско дјело које заступа критику текста, апстрахујући историјски континуитет и развој књижевности". Кајзерова „идеја о стилу дјела, иако опозитна идеји о стилу писиа, широко је прихваћена у другој половини вијека" (171). За Емила Штајгера Н. Вуковић ће рећи да је испољио „највише оригиналности о стилу”, и да су у његовим „Погледима на феномен стила битна два става (1) стил се остварује у тоталитету дјела, односно у међусобном прожимању свих елемената његове структуре и (2) стилови (лирски, епски и драмски) постоје као атемпоралне категорије” (171172). Суштину и једног и другог става Н. Вуковић јасно и прегледно објашњава.

Уз Кајзерова и Штајгерова схватања стилистике, у овом поглављу о интерференцији лингвистичког и књижевног правца Н. Вуковић ће представити и стилистичка учења двојице совјетских стилистичара: Михаила Бахтина и Виктора Виноградова.

Иако стилистика и лингвистика нису биле основне дисциплине његовог интересовања, својим је схватањима Михаил Бахтин битно утицао на развој и једне и друге. У својим бројним дјелима „изнио је врло широк круг стилстичких тема и идеја: од проблема ријечи у говору и умјетничком тексту, преко 
теорије знака и стилистике текста и жанра, до преиспитивања концепција и односа лингвистике, стилистике и поетике". Бахтин је познат и по томе што је износио оригиналне идеје и образложења о питањима директног и индиректног говора, о дијалогизованој ријечи и дијалогичности језика и текста, о питању туђег говора, о проблему текста и његове анализе, о односима језичких и књижевних дисциплина и др. Међу тим темама ипак су двије главне, посебно важне, ако не и најважније у Бахтиновим стилистичким погледима, а то су: (1) дијалогичност језика, и (2) стилистика жанра. Те двије централне стилистичке Бахтинове теме Н. Вуковић ће детаљно у књизи освјетлити.

За развој интерферентне језичко-књижевне стилистике велики значај има и учење Виктора Виноградова, као једног од најзначајнијих совјетских стилистичара. Виноградов сматра да не постоји једна него три стилистике, и то: 1) стилистика језика, у чијој је основи стилистичка концепција женевске школе; 2) стилистика говора, у чијој основи је стилистичка идеја минхенске школе, и 3) стилистичка умјетничке книжевности, која је посебна стилистика која проучава стилистичку употребу језика у оквиру књижевности. Н. Вуковић у књизи даје шири осврт управо на Виноградовљево тумачење стилистике умјетничке књижевности.

Исходиште генетичког правияа у стилистищи није у сосировској лингвистичкој школи, него у школи њемачког идеализма, чији је утемељивач Хуго Шухарт, који је сматрао да је језик творевина појединца генерализована имитацијом колектива који га прихвата. Пошто је тековина појединца, језик је директно од појединца зависан, и то од начина и услова његовог живота, као и његовог темперамента, културе, старости, пола и сл. Дакле, ,језик као систем је небитан, битна је индивидуална, тј. стилистичка, реализација језика. Она је једино креативна, у њеном крилу се стварају промјене и иновације и обогаћује језик" (182). Таква стилистика зове се и идеалистичка или неоидеалистичка стилистика. Њени главни представници су Карл Фослер, професор Минхенског универзитета и оснивач минхенске стилистичке школе, Бенедето Кроче, и Лео Шпицер, професор романске филологије у Марбургу и Келну. Фослер је главни представник неоидеалистичког схватања, према коме је књижевност „само ваљана употреба језика, а писци само даровити појединци који језик ваљано (много боље од обичних људи) употребљавају. Писац, као нека врста специфичног магнета, руковођен естетским фактором укуса, окупља језичке чињенице, стварајући од њих лични језички систем, тј. лични стил”, при чему су „личност и стил увијек повезани: пишући дјело писац увијек у њега уноси властиту личност" (182-183).

Бенедето Кроче, италијански филозоф, идеалиста, сматрао је да постоје двије темељне форме људског сазнања: интуитивна, до које се долази путем фантазије, и логичка, до које се долази путем интелекта. Интуииију, као специ- 
фичну форму људског сазнања, Кроче сматра главним узроком умјетничког стварања. Интуиција се у језику испољава кроз израз, који је битно различит од комуникације и представља основу стила и основу умјетности уопште.

Лео Шпицер је „вјероватно најзначајнији представник овог правца” (184). Шпицера у првом реду „интересује лични стил писиа, тј. његова одступања од колективног и очекиваног језичког израза”, с тим да та одступања „настају као посљедица ауторове личне психологије, његових личних потреба, комплекса и неприлагођености" (184) Такав одступања Шпицер назива девијачијама, с тим да као најизразитијим примјерима девијација сматра комплексе и дефекте. И управу су „девијације узрок стила”, будући да „психичке девијације аутора проузрокују девијације у његовом дјелу”, тако да су ,језичка одступања и варирања у тексту проистекла из ауторових индивидиуалних потреба" (184). Из тога проистиче да је „на основу анализе текстовних, односно стилских, девијација, могуће тај (ауотров) живот разоткрити, односно проникнути у најдубље ирационалне зоне" (184). Шпицерово учење, закључује Н. Вуковић, имало је много присталица и сљедбеника, посебно у САД, гдје је формирана цијела школа - нова стилистика, унутар које су покренуте многе за стилистику значајне идеје: од типологије стилова (Д. Алонсо) до типологије визија cвијета (Л. Голдман), с тим да је идејама нове стилистике близак и Нијемац Х. А. Хацвелд, „који је можда ипак више инклинирао оном правцу који је обично познат под називом стил епохе" (187).

И управо је стил епохе тема наредног поглавља књиге Н. Вуковића. Стил епохе је везан за истраживања у ликовним умјетностима. Термине као што су „романски стил”, „горски стил”, „дорски стил” и сл. „историчари умјетности почињу третирати као временске категорије, односно као епохе у којима је владао одређен тип стила", с тим да су категорију стилске епохе прихватили и књижевни историчари, па су се тако јавили термини „романтизам”, „реализам”, „натурализам” и др. као називи за стилске епохе књижевне историје. Стил у опцији стила епохе се „суштински темељи на компонентама општег карактера: укусу, моди, традицији, класици, ауторитетима у литератури и сфери културног живота, владајућим естетикама итд." (188-189). Након што је дао анализу најбитнијих научних доприноса у истраживањима стила епохе, посебно наглашавајући научне резултате швајцарског историчара умјетности Хајнриха Велфлина а у оквору науке о књижевности представљене у његовој књизи Основни појмови умјетности из 1915. године, Ново Вуковић ће у закључку разматрања о стилу епохе указати на два крупна недостатка овога стилистичког правца. „Први велики недостатак има коријене у чињеници да се тај правац зачео у нејезичким умјетностима и да се из њих, некако сувише директно, и без поштовања њене специфичности, пренио у књижевност”, док je „други велики проблем овог метода узрокован чињеницом да се врло тешко може наћи чист стилски тип, који би потпуно репрезентовао одређену епоху, 
што је условило да се чистоћа типа углавном добија конструктивним путем и третира као идеал” (192-193).

Логично је да се књига о путевима стилистичке идеје заврши указивањем на нове идеје и концегпиије у истражсиваюу стила. А управо тако Н. Вуковић насловљава посљедње поглавље своје књиге. У том поглављу он као најновије, а значајне стилистичке идеје види: 1. обнову реторике, 2. „реконщепщију стилситике” према Жан-Мишелу Адаму, и 3. семиостилситику Жоржа Молинијеа.

Успон структурализма и примјена његових принципа у областима истраживања дискурса и/или текста доводи до конституисања низа нових пројеката и дисциплина, као нпр. на књижевном плану француске „нове критике” чији је главни представник Ролан Барт, који је „свјестан да је конципирање једне нове, структуралистичке, реторике у току" (195). Није Барт једини, него се све чешће код већег борја аутора (нпр. Ж. Женета, Ц. Тодорова, Н. Рувеа и др.) јавља идеја да се обнови реторика. И да се постави на нове основе. У директну обнову реторике креће једна струја логичара коју предводи белгијски филозоф Хаим Перелман, који први употребљава термин „нова реторика” (1958), а саму реторику конципира као теорију аргументације. (О Перелмановој новој реторици в. Хасанбеговић 1988). Но, будући да се бавила само теоријом аргументације, а не и теоријом елокуције, Перелманова нова реторика није била битна за стилистичку идеју.

Пројекат „нове реторике” сличан Перелмановом, али не на правном, него на стилистичком плану обавила је група аутора Центра за поетичке студије Универзитета у Лијежу, коју су сачињавали Жак Дибоа, Френсис Едлин, Жан-Мари Клинкенберг, Филип Менге, Франсоа Пир и Хедлин Тринон. Под заједничким називом Група $\mu$ - при чему је ово $\mu$ почетно слово грчки исписаног термина метабола, као једног од најзначајнијих термина ове реторике - они објављују 1970. године Општу реторику, као једно од најзначајнијих стилистичких дјела уопште. Н. Вуковић врло исцрпно а прегледно даје приказ овога дјела лијешких новореторичара. Опита реторика, уз уводни дио у коме се разматра међуоднос поетике и реторике, садржи два комплементарна реторичка дијела, која су, у ствари, двије специфичне реторике: фундаментална и општа.

Предмет фундаменталне реторике јесте нова класификација реторичких или стилских фигура. Лијежани умјесто термина фигура уводе термин метабола. За опис једне метаболе потребни су одређени елементи, а то су: отклон, маркер, инваријанта и етос. А све метаболе настају вршењем четирију реторичких операција, под којим се подразумијевају нешто модификовани поступци настанка стилских фигура старе реторике, а то су: укидање, додавање, истовремено укидање и додавање, и пермутација. Класификација метабола изведена је на принципима теорије информација и своди се на двије велике 
групе. Прву чине метаболе које се односе на језички израз („граматичке метаболе”), а другу метаболе које се односе на садржај („логичке метаболе”). Метаболе језичког израза покривају три домена: 1. домен метаплазми (тиче се операције у сфери звука ријечи, јединица мањих од ријечи и операција у сфери писма), 2. домен метатакси (тиче се операција у структури реченице), и 3. домен метасемема (тичу се замјене семема; то су у ствари тропи). $\mathrm{Me-}$ таболе језичког садржаја тичу се трансформација у домену референције, а ту спадају металогизми (операције које подразумијевају промјене и модификације логичких вриједности, а што су у ствари фигуре мишљења из класичне реторике). У концепцији Лијежана главни (основни) троп није ни метафора ни метонимија, него синегдоха. Матафора и метонимија су сложене фигуре настале комбинацијом синегдоха.

Други дио Опште реторике полази од тога да је „сва четири типа реторичких операција, које функдаментална реторика прати на дореченичном нивоу, могуће пратити и на надреченичном нивоу, односно на нивоу дискурса или текста" (199). Друкчије речено, у првом дијелу реторике обрађују се микрофигуре, а у дугом - макрофигуре. Лијежани разликују двије велике групе макрофигура: 1. фигуре саговорника, и 2. фигуре нараиије. Фигуре саговорника настају на основу разних замјена у бинарним опозицијама у систему личности (нпр. замјена првог лица неким другим; замјена која подразумјева „скривање” лица, замјена једнине и множине и сл.). Лијежани су издвојили и описали шест типова бинарних опозиција које представљају фигуре саговорника. Друга група фигура дискурса или текста за класификациону основу има дистинкцију Л. Хјелмслева између форме и супстанце израза и форме и супстанце садржаја. Лијежани издвајају три типа фигура нарације: 1. фигуре супстанци израза, 2. фигуре форми израза, којих има пет врста (фигуре релације времена, фигуре за догађаје и хронологију, фигуре повезивања догађаја и каузалног детерминизма, фигуре за представљање простора у дискурсу, фигуре везане за тачку гледишта), и 3. фигуре форме садржаја.

У закључку приказа реторичке књиге Групе $\mu \mathrm{H}$. Вуковић ће рећи да су се Лијежани трудили да њихова „концепција 'опште реторике' обухвати све начине изражавања”, али је „евидентно да њих превасходно интересује књижевно изражавање, односно књижевни дискурс. Преузимајући из Јакобсоновог модела поетску функиију и преименујући је у реторичку, они су је поставили као главно поље свог истраживања" (204).

Као другу значајну нову идеју и концепцију у истраживању стила $\mathrm{H}$. Вуковић приказује ,, реконщепщију стилситике” Жан-Мишела Адама. Жан-Мишел Адам је професор француске лингвистике у Лозани и директор Центра за истраживања у тектуалној лингвистици и анализи дискурса. „Сматрајући да су границе између језика и стила, и сљедствено томе између граматике и 
стилистике, непрецизно и вештачки постављене, он настоји да реконципира досадашњу стилистику, превасходно под њом подразумијевајући ону која своје схематско полазиште има у механизму норма-отклон" (206). Суштина реконцепције стилистике Жан-Мишел Адама полази од пет Бајијевих основних теза: (1) креативност се простире широко с ону страну саме књижевне умјетности, (2) обични језик је тај у ком се рађају клице стила, (3) у свему томе битне су „сублимне деформације”, (4) оне су посљедица ефектуације у матерњем језику, (5) књижевна умјетност се карактерише трансформацијом практичних у естетичке интенције, тј. трансформацијом начина у циљ. (206). Сваку од наведених теза Адам објашњава у новом лингвистичком кључу, позивајући се на идеје других лингвиста и/или стилистичара као аргумент (Л. Шпицера, Ж. Женета, В. Виноградова, М. Шефера, П. Валерија, Р. Јакобсона, Н. Трубецког, В. Хлебњикова, Г. Хуга и др.), али и филозофа (М. Жакоба, Л. Арагона, Ж. Делеза, П. Рикера). Те му идеје служе прије свега за „ново читање” Бајијевих теза и потврду њихове (не)актуелности. Циљ Жан-Мишел Адама је „да покуша реинтегрисати феномен стила у једну општу теорију језика и текста која би практично послужила књижевној анализи. Као специјалиста за тепорију текста и анализу дискурса Адам се труди да постави основне линије једне реконцепције не само стилистике него и граматике. На тај начин креира један вид прагматике текста ослоњене на ревитализовану и реконципирану стилистику" (210).

Издвајањем Адамове идеје нове стилистике и њеним ситуирањем у завршно поглавље Н. Вуковић је на својеврстан начин затворио развојни пут модерне стилистичке идеје: она почиње Бајијевом као првом научно аутономном стилистиком, а завршава се Жан-Мишел Адамом као најновијом и најмодернијом, у чијој је основи управо реконцепција темељних поставки управо Бајијеве стилистике. Али Жан-Мишел Адамова „реконцепција стилистике” није и посљедњи стилистички поглед о коме у књизи говори Н. Вуковић. Он је за крај оставио приказ семиостилистике Жоржа Молинијеа. Ж. Молиније, сорбонски професор, у својој књизи Семиостилистика понудио је ,амбициозан пројекат стилистике која би обухватала истраживање стила у свим умјетностима, како вербалним тако и невербалним. Пројект има идеју водиљу у ставу да све умјетности имају исти циљ: да остваре ефекат на конзумента у процесу рецепције. У систему размјене производње и рецепције, на коме почивају и теорија информације и комуникације, и који подразумијева три подједнако важне компоненте, а то су емитер - рецептор - предмет поруке, за стилистику је рецепција најбитнија компонента. У Молинијевом схватању стилистике врло битну улогу игра тзв. актантска стилистика, која „проучава структуру модела емисије и рецепције текста као дискурса", и она је битна не само за књижевни него и за било који други дискурс (211). Молинијеве стилистичке идеје сагласне су са идејама интегралистичке критике засноване на основама 
семиотике, које је подржавао велики број његових савременика, између којих и Жерар Женет, Луј Марон и Рене Деморис. Међутим, у концепцији стилистике као интегралистичке критике Молинијеу је више ослонац Л. Хјелмслев него Чарлс Перс као оснивач семиотике (о Перс-Морисовој семиотици в. Морис 1975). Молиније усваја Хјелмслевљев четворни модел према коме постоје два плана: план израза и план садржине од којих сваки има своју супстанцу и своју форму (в. Хјелмслев 1980: 45-60). „Док је и супстанцу и форму у вербалним умјетнсотима лако препознати (супстанца израза је звук, односно графички знак; форма израза је одбир речи, фраза фигура - тј. оно што се у старој реторици називало elocutio, или у традиционалној критици стил, форма садржине, пак, је скуп макроиструктуралних фигура другог нивоа, тј. великих аргументативних и наратиовних топоса, начина описивања, објашњавања и сл.), дотле у случају других умјетности (нпр. сликарства и музике), постоје тешкоће у идентификацији супстанце садржине" (213-214). Молинијева је тежња да оба плана - и план израза и план садржине - посматра шире и комплексне у сродним умјетностима с тежњом да установи да постоји њихова велика блискост, при чему ,језик вербалне умјетности служи као метајезик невербалних умјетности, и то не само у сврху описивања тих језика, него прије свега у сврху одређивања супстанце садржине тих умјетности" (214).

Једно од најбитнијих стилистичких питања на које Молиније тражи одговор јесте: како је један исти афекат третиран различитим материјалима у различитим умјетностима, односно како је један стил као један естетички манир реализован кроз разне материјале, разне умјетности, њихове жанрове и посебна дјела? Као одговор на то питање Молиније нуди два приступа. Први је интер-семиотички, који подразумијева постојање мијешане умјетности, и у оквиру кога се издвајају интер-стилеме као посебан тип стилема, које би требало да изучава посебна дисциплина, као вид критике, која се зове интер-семиотика. Други приступ је транс-семиотички, који подразумијева начин третирања истога афекта кроз материјале различитих умјетности; у оквиру тог приступа издвајају се транс-стилеме као посебна врста стилема, које треба да проучава транс-семиотика стилистике као посебна дисциплина.

Приказ Молинијева „стилистика” на крају књиге логичан је завршетак разматраног пута или путева стилистичких идеја. Ту се уочава паралелизам између пута лингвистике и пута стилистике. Заснивајући лингвистику као аутономну науку, Сосир јој је за предмет истраживања одредио коे као апстрактни систем знакова и правила њиховог комбиновања, искључивши је и из природних и из историјских наука, сматрајући да она „спада у групу наука, која би, ако не постоји, требало да постоји под именом семиологија - наука о знаковима или проучавање онога што се дешава када човек покуша да изрази своје мисли захваљујући обавезном договору" (Сосир 2004: 251). Друкчије речено, Сосир сматра да лингвистика припада науци која се може осмислити 
као „наука која проучава живот знакова унутар друштвеног живота; она би представљала део социјалне психологије и, сходно томе, опште психологије; ми ћемо је назвати семиологијом (од грчког sēmeîon, „знак”)” (Sosir 1996: 39). Стилистика као аутономна научна дисциплина настала је управо у оквиру сосировске лингвистике, и њен оснивач Ш. Баји одредио јој је врло узак предмет истраживања: колективну афективност. Она је била строго лингвистичка дисциплина, са стилемом као структурно и/или семантички онеобичајеном јединицом појачане изражајности (в. Мистрик 1967). У свом развојном путу Бајијевске идеје су ширене, модификоване, предмет стилистике се усложњавао, она је постала најмање лингвистичко-књижевна дисциплина. И као и лингвистика на крају, код Жоржа Молинијеа, подведена је под семиотику, постајући семиотичка стилистика, са интерсемиотичком и транссемиотичком стилистиком као подврстама, с тим да јој је основна јединица истраживања опет стилема, са интерстилемама и трансстилемама као подтиповима. И као да нас то, након освјетљења предмета и садржаја ове књиге Н. Вуковића, упућује на закључак да је стилистика на цијелом свом путу од Бајија до Молинијеа од лингвистилистике до семиотичке стилистике - остала вјерна једино свом темељном лингвистичком језгру.

\section{ИЗВОРИ}

Вуковић 2000: Novo Vuković, Putevi stilističke ideje, Podgorica - Nikšić: Jasen. Вуковић 2004: Ново Вуковић (1937-2002): Споменица академику Нову Вуковићу, уредио Ранислав Булатовић, Подгорица: Црногорска академија наука и умјетности.

\section{ЛИТЕРАТУРА}

Анђелић 1930: Ђорђе Анђелић, $О$ стилу и композииији, Београд: Геца Кон.

Анђелић 1932: Ђорђе Анђелић, Теорија књижевности, Београд: Геца Кон.

Гиро 1964: Pierre Guiraud, Stilistika, prevod s francuskog Branko Džakula, Sarajevo: „Veselin Masleša”.

Јовановић 2002: Јелена Јовановић, Нова књига о старој идеји (Ново Вуковић, 'Путеви стилистичке идеје', Јасен, Никшић, 2000)", Книжевност и језик, XLIX/3-4, 159-165.

Јовановић Симић 2012: Јелена Јовановић Симић, Научни стил Нова Вуковића (Текстуална интертекстуална анализа научног дискурса у књизи Путеви стилистичке идеје), у: Српско језичко насљеђе 
на простору данашье Црне Горе и српски језик данас, зборник радова са међународног научног скупа, уредник Јелица Стојановић, Никшић: Матица српска - Друштво чланова у Црној Гори, 241-248.

Ковачевић 2018: Милош Ковачевић, Мјесто Радоја Симића у србистици, с посебним освртом на његове стилистичке доприносе, у: Научни доприноси Радоја Симића, уредници Милош Ковачевић, Јелена Петковић и Владимир Поломац, Крагујевац: ФИЛУМ, Београд: Јасен, 47-66.

Ковачевић 2018а: Милош Ковачевић, Стилистички доприноси Милорада Ћорца, у: Милорад Ћораи педагог и научни радник, уредник Голуб Јашовић, Косовска Митровица: Филозофски факултет Универзитета у Приштини, 129-144.

Мистрик 1967: Јозеф Мистрик, Jazykovo-intonačné prostriedky recitátora, Братислава.

Морис 1975: Čarls Moris, Osnovi teorije o znacima, Beograd: BIGZ.

Павловић 1960: Миливој Павловић, Проблеми стила, Београд: Научна књига.

Павловић 1969: Миливој Павловић, Проблеми и принципи стилистике, Београд: Завод за издавање уџбеника Социјалистичке Републике Србије.

Прањић ${ }^{3}$ 1985: Krunoslav Pranjić, Jezik i književno djelo. Ogledi za lingvostilističku analizu književnih tekstova, Beograd: Nova Prosveta.

Радуловић 2004: Zorica Radulović, O stilističkoj misli Nova Vukovića, u: Iz jezičke problematike, Podgorica: Kulturno prosvjetna zajednica Podgorice, 138-145.

Симић 1998: Радоје Симић, Општа стилистика, Београд: НДПСЈ.

Симић 2000: Радоје Симић, Стилистика српског језика I: принципи стилске анализе и фоностилистика, Београд: НДПСЈ.

Симић/Јовановић 2002: Р. Симић, Ј. Јовановић, Основи теорије функционалних стилова, Београд: НДПСЈ, Мала лингвистичка библиотека; Никшић: Јасен.

Сосир 1996: Ferdinand de Sosir, Kurs opšte lingvistike, kritičko izdanje priredio Tulio de Mauro, a sa francuskog i italijanskog preveli Dušanka Točanac Milivojev, Milorad Arsenijević, Snežana Gudurić i Aleksandar Đukić, Sremski Karlovci - Novi Sad: Izdavačka knjižarnica Zorana Stojanovića. 
Сосир 2004: Ferdinand de Sosir, Spisi iz opšte lingvistike, priredili i izdali Simon Buke i Rudolf Engler u saradnji sa Antoanetom Val, a sa francuskog preveli Dušanka Točanac Milivojev, Snežana Gudurić i Nada Graovac, Sremski Karlovci - Novi Sad: Izdavačka knjižarnica Zorana Stojanovića.

Тартаља 2008: Иво Тартаља, Књижевна естетика Ђорђа Анђелића, <http:/ www.doiserbia.nb.rs/img/doi/0350-6673/2008/0350-66730804109T. pdf> (приступ: 15. 7. 2020).

Тошовић 1988: Branko Tošović, Funkcionalni stilovi, Sarajevo: Svjetlost.

Тошовић 2015: Бранко Тошович, Интернет-стилистика, Москва: Издательство „Флинта” и „Наука”.

hорац 1974: Milorad Ćorac, Stilistika srskohrvatskog književnog jezika, Beograd: Naučna knjiga.

Хасанбеговић 1988: Jasmina Hasanbegović, Perelmanova pravna logika kao nova retorika, Beograd: Istraživačko-izdavački centar SSO Srbije.

Хјелмслев 1980: Louis Hjelmslev, Prolegomena teoriji jezika, prevod s njemačkog Ante Stamać, Zagreb: Grafički zavod Hrvatske.

Чаркић 2002: Милосав Чаркић, Увод у стилистику, Београд: Научна књига.

\section{STYLISTIC CONTRIBUTIONS OF NOVO VUKOVIĆ}

\section{Summary}

The paper gives an overview of stylistic contributions of Novo Vuković presented in his book Putevi stilističke ideje [Paths of the Stylistic Idea], which is doubtless the best stylistic manual that exceeds the frameworks of Serbistics and/or Serbo-Croatistics. This stylistic manual can be compared to the world best stylistic manuals. Novo Vuković does not disregard a single fact important for elucidating the history and current state of stylistics: from explaining all relevant concepts and problems of style and stylistics to outlining the historical path of the stylistic idea, from its anticipation in ancient rhetoric to a highly complex current situation.

Novo Vuković uses sound arguments to shed light on the path of stylistics from its scientific beginnings of Charles Bally within Saussure's linguistics, with the styleme as the basic minimum structurally and/or semantically defamiliarised unit of pronounced expressiveness. On their development path, the ideas of C. Bally were spread, modified, and the subject matter of stylistics became more complex - it became a linguistic-literary discipline to the least extent. Just like the linguistics of F. de Saussure, in the late $20^{\text {th }}$ century stylistics (according to the teaching of Georges Molinié) was subsumed under semiotics, becoming 
semiotic stylistics, with intersemiotic and transsemiotic stylistics as subtypes, with the basic research unit remaining the styleme, with interstylemes and transstylemes as subtypes.

All this suggests that on its entire path - from linguostylistics to semiotic stylistics, stylistics remained faithful only to its fundamental linguistic core.

Keywords: Novo Vuković, stylistics, linguistic stylistics, literary stylistics, development of stylistics, types of stylistics, stylistic (sub)disciplines.

Miloš M. Kovačević 